\title{
COMPLICATIONS OF TEMPOROMANDIBULAR JOINT ARTHROCENTESIS
}

\author{
Kıvanc Berke Ak, Muazzez Suzen, Cagrı Delilbası \\ Department of oral and maxillofacial surgery, Faculty of dentistry \\ Istanbul Medipol University, Istanbul, Turkey
}

Primljen/Received 29. 01. 2020. god.

Abstract: Arthrocentesis is a frequently performed and accepted minimally invasive and predictable procedure in the treatment of temporomandibular joint disorders. This review aimed to evaluate arthrocentesis complications. The literature search has included PubMed, Google Scholar, and EMBASE databases by using terms "((TMJ OR TEMPOROMANDIBULAR JOINT OR TMD OR TEMPOROMANDIBULAR DISORDER) AND ARTHROCENTESIS) AND COMPLICATION". Publications up to 2019 were examined. Seven studies involving arthrocentesis complications were included. Although arthrocentesis is considered as a cost-effective and safe procedure, complications may be seen due to its proximity to important anatomical structures. Most of these complications are short-lived and can easily be managed in the outpatient clinic; however, some severe complications have rarely been reported in the literature. The practitioners who perform this procedure should be aware of these possible complications and be able to manage them in the clinic.

Key words: Arthrocentesis, Complication, Temporomandibular joint, TMJ.

\section{INTRODUCTION}

Temporomandibular joint disorders (TMD) is a term that covers many closely related conditions, which include functional changes and pathological conditions of temporomandibular joint (TMJ), maxillofacial region, and the related muscles. It is most commonly seen in young women and covers $10 \%$ of the population. In $80 \%$ of patients with TMD, internal derangement (ID) of the TMJ has been reported in the literature (1). Symptoms of TMJ ID anchored disc phenomenon, painful click and/or crepitus, disc displacement with reduction, joint erosion, joint flattening, closed lock, reduced jaw mobility, osteophytes, and free radicals and inflammatory mediators in synovial fluid $(1,2,3)$.
Prihvaćen/Accepted 11. 04. 2020. god.

TMD can be managed conservatively or surgically. Conservative treatment includes physiotherapy, chemotherapy (analgesics, anti-inflammatories, muscle relaxants), rest therapy, and splint therapy. Surgical treatments may include invasive (open approaches) or minimally invasive treatments. Most patients with ID can be treated successfully by conservative treatment, which can also prevent the progress of the disorder. The purpose of therapy is to eliminate predisposing factors. Open surgical procedures are the treatment methods used only when all other conservative and minimally invasive treatments have been tried and failed. This approach was developed to reduce the risk of complications $(2,3,4)$.

Arthroscopy and arthrocentesis are minimally invasive surgical methods used for the treatment or diagnosis of intraarticular pathologies (5). Ohnishi performed TMJ lavage by the very first time in 1990 (6). Nitzan et al. described the TMJ arthrocentesis technique by using two needles to lavage the upper joint space, and this technique is frequently performed today (7). Arthrocentesis principles are reducing intraarticular viscosity, clearing inflammatory and pain mediators, allowing nutrient perfusion. As a result, the disc can make free sliding movement comfortable. Clinical outcomes are the reduction of pain, joint sounds, and improve mouth opening (8). Arthrocentesis has been suggested originally for the treatment of painful limited mouth opening caused by acute onset TMJ derangement. Now it is a universal procedure accepted in the treatment and diagnosis of ID, continuing pain in TMJ, unresponsive to conservative management, anterior disc displacement with and without reduction and associated osteoarthritis, and rheumatoid arthritis (9).

Although arthrocentesis is a clinically effective and minimally invasive treatment, there are reported complications. However, its complication rate remains 
unclear (1-11). This study aimed to review and summarize the reported complications of arthrocentesis.

\section{MATERIALS AND METHODS}

We evaluated the search engines, PubMed and Google Scholar, and EMBASE, using the terms "(TMJ OR TEMPOROMANDIBULAR JOINT OR TMD OR TEMPOROMANDIBULAR DISORDER) AND ARTHROCENTESIS) AND COMPLICATION." These keywords were used in the same format for all databases. No time limitation applied to filtration; therefore, all the researches until 2019 December were included. Only human trials were taken into consideration.

The inclusion criteria are; English and Turkish language articles, case reports, or case series describing a clinical complication of TMJ arthrocentesis. Animal researches were excluded. Two researchers cross-checked to ensure that all relevant studies were included. The same two researchers examined the ab- stracts of the studies. Content relationship and degree of inclusion criteria were assessed for each reviewed publication. Full texts of the articles that fit the criteria of the research obtained. The articles included in the study were shown in Table 1.

\section{RESULTS}

As a result of our literature search, eight articles were found in PubMed, 1690 articles were found in Google Scholar, and 98 articles were found in EMBASE. As a result of the selection criteria, seven articles were included in the research. Complications and demographic data reported in the articles were shown in Table 1. One article is about Vertiginous crisis, and one is about facial nerve paralysis with lingual and inferior alveolar nerve anesthesia, one is about just lingual and inferior alveolar nerve anesthesia, one is about extradural hematoma, one is about otologic symptoms, three of are about case series which reports their complications and their

Table 1. Summary of articles from databases included in the study

\begin{tabular}{|c|c|c|c|}
\hline Author/year & Type of Article & Patient/Gender & Complications \\
\hline Vaira et all $/ 2016$ & Case report & $1 / \mathrm{F}$ & *Vertigo \\
\hline Efeoglu et all $/ 2010$ & Case report & $1 / \mathrm{F}$ & *Mandibular anesthesia \\
\hline Yavuz GY et all./2018 & Retrospective & $96(58 \mathrm{~F}, 38 \mathrm{M}) / 102$ & $\begin{array}{l}\text { *Temporary swelling } \\
\text { *hemorrhage } \\
\text { * facial paralysis } \\
\text { *lingual anesthesia } \\
\text { *inferior nerve anesthesia } \\
\text { *tachycardia } \\
\text { *syncope } \\
\text { *dizziness } \\
\text { *severe pain } \\
\text { *limitation of mouth opening }\end{array}$ \\
\hline Aliyev T et all /2019 & Case report & $1 / \mathrm{M}$ & $\begin{array}{l}\text { *temporary facial paralysis } \\
\text { *lingual anesthesia } \\
\text { *inferior nerve anesthesia } \\
\text { *dizziness } \\
\text { *nausea }\end{array}$ \\
\hline Vaira et all $/ 2017$ & Retrospective & $315(252 \mathrm{~F}, 63 \mathrm{M}) / 433$ & $\begin{array}{l}\text { *Temporary swelling } \\
\text { *external auditory canal swelling } \\
\text { *ipsilateral temporary open bite } \\
\text { *frontalis and orbicularis oculis paresis } \\
\text { *preauricular hematoma } \\
\text { *vertigo }\end{array}$ \\
\hline Carrol all /1998 & Case report & $1 / \mathrm{F}$ & *Extradural haematoma \\
\hline Senturk et all / 2016 & Retrospective & $22(18 \mathrm{~F}, 4 \mathrm{M}) /-$ & $\begin{array}{l}\text { *Postop pain } \\
\text { *Fluid extravasation } \\
\text { *Temporary facial paralysis } \\
\text { *Bleeding } \\
\text { *Irritating dizziness } \\
\text { *Mandibular restriction }\end{array}$ \\
\hline
\end{tabular}


rates. The case series introduced temporary local swelling, hemorrhage, facial paralysis, lingual anesthesia, inferior mandibular nerve anesthesia, tachycardia, syncope, dizziness, severe pain, limitation of mouth opening, preauricular hematoma, external auditory canal swelling and bleeding, complications. All these articles were published between 1998-2019. The follow-up period changed from 1 day to three months.

\section{DISCUSSION}

TMJ arthrocentesis is frequently used in the treatment of internal disorders characterized by multifactorial etiology. Arthrocentesis is a minimally invasive, cost-effective, with a high success rate $(91 \%)$ procedure that can easily be performed under local anesthesia in the clinical conditions. Arthrocentesis method removes catabolism products, inflammatory cells, and adhesions in the joint fluid; therefore, it reduces pain and increases interincisal distance and stops disease progression $(7,12,13)$.

Prior studies have noted the safety of arthrocentesis procedure; however, like all surgical procedures, several complications have also been reported. The causes of complications may occur due to the anatomy of the joint, the physician's experience, and the arthrocentesis technique $(10,14,15)$.

Complications can occur commonly secondary to mechanical damage of cannula or local anesthesia diffusion. The reported complications caused by these two main reasons affecting the middle ear are allergic reactions, facial paralysis, and vertigo, as well as dizziness and hearing difficulty (16).

In 22 TMJ arthrocentesis cases reported by @enturk et al. (12), pain (27.3\%), temporary facial paralysis $(21.2 \%)$, fluid extravasation $(18.92 \%)$, bleeding (13.51\%), mandibular restriction (13.51\%) and irritating dizziness $(5.41 \%)$ occurred. They concluded that these complication rates are less than arthroscopy techniques.

Vaira et al. (17) demonstrated an unusual complication a 48-year-old female suffered from independently regressing short-term vertigo attacks. The attack begins just after the local anesthesia (mepivacaine 2\% and 1:200,000 epinephrine) injection before arthrocentesis. The author explained that the patient was troubling of transarticular penetration. The infiltrated anesthetic solution reached the semicircular canals near the inner ear that causes nausea, vomiting, and grade three nystagmus. When the effect of the anesthetic solution disappeared, the symptoms relieved, and the patient had no other complications.

Vaira et al. (3) in 2018 evaluated complications in 225 women and 53 male patients after 433 arthrocentesis procedures evaluated the complications. They detec- ted temporary swelling of the periarticular tissues $(95.1 \%)$ and the external auditory canal $(23.5 \%)$, ipsilateral temporary open bite $(68.8 \%)$, frontalis and orbicularis oculi paresis $(65.1 \%)$, preauricular hematoma $(0.4 \%)$, and a case of vertigo $(0.2 \%)$. The stated that these complications were temporary and occurred due to anesthetic effect or soft tissue edema. All the complications were managed uneventfully on outpatient basis.

In a case reported by Efeoglu et al (18), a perforation was unintentionally created in the medial wall of the joint capsule during the placement of the cannula in the upper joint cavity. As a result of this, saline and local anesthetic agents spread to the infratemporal fossa. Anesthesia developed in the mandibular nerve adjacent to the joint. This was a rare complication od arthrocentesis and was essential to emphasize the importance of capsule integrity during this procedure.

As mentioned in the literature by Yavuz et al. (19), eighteen complications were bserved in 102 arthrocentesis procedures. Temporary swelling $(0.98 \%)$, temporary intracranial bleeding $(0.98 \%)$, facial paralysis $(1.96 \%)$, lingual anesthesia $(0.98 \%)$, inferior nerve anesthesia $(0.98 \%)$, tachycardia $(0.98 \%)$, syncope (2.94\%), dizziness $(4.9 \%)$, severe pain $(0.98 \%)$, and limitation of mouth opening $(1.96 \%)$ noted. The overall rate of complications regarding the literature of arthrocentesis was $17.65 \%$ in all patients.

Aliyev et al. (20) reported a complication about developed temporary facial paralysis with mandibular and lingual nerve anesthesia. The 55-year-old male patient suffered this complication just one hour after the arthrocentesis. This complication explained by mechanical damage caused by cannula, which led to anesthetic solution diffuse to the infratemporal fossa. No further complications were observed in the following period. The reported complication resolved spontaneously. No persistent complications were detected during the postoperative follow-up.

Carrol et al. (10) reported the most uncommon complication. Following the right TMJ arthrocentesis and lavage for TMJ dysfunction, a 59-year-old woman complained about drowsiness and developed left hemiparesis. Computed tomography revealed that the cannula crossed the temporomandibular joint and perforated the intracranial part of the middle meningeal artery where extradural hematoma occurred. Hematoma removed by neurosurgeon intervention. No dural perforation or cranial bone damage reported. Severe symptoms after the procedure should be monitored carefully in order not to overlook life-threating complications.

The complication rate of arthrocentesis is low. Facial nerve trauma, preauricular hematoma, superficial temporal artery trauma, arteriovenous fistula, intraarticular hemorrhage, intracranial perforation, extradural 
hematoma, intraarticular needle fracture, extraarticular injection, and fluid accumulation and allergic reactions to anesthetic agents or drugs are the up to date reported complications $(10,19,21)$.

In conclusion, although arthrocentesis is considered as a safe and predictable procedure, complications may be seen due to its close proximity to important anatomical structures. Most of these complications can be easily managed in the clinics although some maybe more serious.

\section{CONCLUSION}

TMJ arthrocentesis is the removal of joint fluid containing many degradation products and inflammatory mediators. This surgical procedure is performed by inserting needles or small cannulae into the TMJ to break up intraarticular adhesions. According to literature, It has a minimum number of significant complications. Compared with other surgical techniques applied to TMJ, it is easy to determine that it is a minimally invasive treatment technique. Complications of the procedure are usually temporary. The main reason for temporary complications is the extravasation of the anesthetic solution or irrigation solution to the soft tissues. TMJ and neurocranium are in a close relationship. Due to the neighboring, serious complications can occur if cannula passes on et on other side.
Although the complication rates of arthrosynthesis are quite low, surgeons should be aware of vascular and nerve damage. Upper joint space and neurocranium are separated by a thin bone lamina. The surgeon should be aware of it due to avoid intracranial complications, which leads to immediate hospitalization for the patient. Proper knowledge of the possible complications and their frequency helps the surgeon achieve the procedure successfully. TME arthrocentesis is a less complicated procedure that does not require additional equipment and is easy to perform. It is a minimally invasive method that is effective in reducing the pain of TMD and restoring function.
Abbreviations
TMJ - temporomandibular joint
TMD - temporomandibular disorder
ID - internal derangement

Conflict of Interests: The authors declare that there are no conflicts of interest related to this article.

Funding: None

\section{Licensing}

This work is licensed under a Creative Commons Attribution 4.0 International (CC BY 4.0) License.

\title{
Sažetak
}

\section{KOMPLIKACIJE ARTROCENTEZE TEMPOROMANDIBULARNOG ZGLOBA}

\author{
Kıvanc Berke Ak, Muazzez Suzen, Cagrı Delilbası
}

Department of oral and maxillofacial surgery, Faculty of dentistry Istanbul Medipol University, Istanbul, Turkey

Artrocenteza je procedura, koja se često koristi i prihvaćena je kao minimalno invazivna i prediktivna u lečenju oboljenja temporomandibularnog zgloba. Cilj rada je procena komplikcija artrocenteze. Pregled literature uključuje PubMed, Google Scholar i EMBASE baze podataka, koristeći termine „(TMJ ili TEMPOROMANDIBULARNI ZGLOB ILI TMB ILI OBOLJENJA TEMPOROMANDIBULARNOG ZGLOBA) I ARTROCENTEZA) I KOMPLIKACIJE" Publikacije do 2019.te su bile uzete u razmatranje. Sedam studi-

\section{REFERENCES}

1. Al-Moraissi EA. Arthroscopy versus arthrocentesis in the management of internal derangement of the temporomandibular joint: A systematic review and meta-analysis. Int J Oral Maxillofac Surg. 2015; 44(1): 104-12.

2. Machon V, Hirjak D, Lukas J. Therapy of the osteoarthritis of the temporomandibular joint. J Cranio-Maxillofacial Surg. 2011; 39(2): 127-30. ja koje su uključivale komplikacije artrocenteze su bile uključene. Iako je artrocenteza relativno jeftina, tj. finansijski efikasna i sigurna procedura, komplikacije mogu da se jave zbog blizine prikazanih anatomskih struktura. Najviše komplikacija je kratkog trajanja i mogu lako biti rešene $u$ ambulatnim uslovima; iako su i neke teže komplikacije takođe bile zabeležene u literari. Lekari koji izvode ovu proceduru trebalo bi da budu svesni mogućih komplikacija ove procedure i da budu spremni da iste i adekvatno tretiraju.

3. Vaira LA, Raho MT, Soma D, Salzano G, Dell'aversana Orabona G, Piombino P, et al. Complications and post-operative sequelae of temporomandibular joint arthrocentesis. Cranio. 2018; 36(4): 264-7.

4. Randolph CS, Greene CS, Moretti R, Forbes D, Perry HT. Conservative management of temporomandibular disorders: A posttreatment comparison between patients from a university clinic and from private practice. Am J Orthod Dentofac Orthop. 1990; 98(1): 77-82. 
5. Chowdhury SKR, Saxena V, Rajkumar K, Shadamarshan RA. Complications of diagnostic TMJ Arthroscopy: an institutional study. J Maxillofac Oral Surg. 2019; 18(4): 531-5.

6. Ohnishi M. Arthroscopy and arthroscopic surgery of the temporomandibular joint (T.M.J.). Rev Stomatol Chir Maxillofac. 1990; 91(2): 143-50.

7. Nitzan DW, Dolwick MF, Martinez GA. Temporomandibular joint arthrocentesis: A simplified treatment for severe, limited mouth opening. J Oral Maxillofac Surg. 1991; 49(11): 1163-7.

8. Kaneyama K, Segami N, Nishimura M, Sato J, Fujimura $\mathrm{K}$, Yoshimura $\mathrm{H}$. The ideal lavage volume for removing bradykinin, interleukin-6, and protein from the temporomandibular joint by arthrocentesis. J Oral Maxillofac Surg. 2004; 62(6): 657-61.

9. Kuruvilla VE, Prasad K. Arthrocentesis in TMJ internal derangement: a prospective study. J Maxillofac Oral Surg. 2012; 11(1): 53-6.

10. Carroll TA, Smith K, Jakubowski J. Extradural haematoma following temporomandibular joint arthrocentesis and lavage. Br J Neurosurg. 2000; 14(2): 152-4.

11. Tozoglu S, Bayramoglu Z, Ozkan O. Outcome of otologic symptoms after temporomandibular joint arthrocentesis. J Craniofac Surg. 2015; 26(4): e344-7.

12. Senturk MF, Kocer G, Bulte M, Cinaaksoy M. Operasyon esnasinda ve sonrasinda görülen temporomandibuler eklem (Tme) artrosentez komplikasyonlari. Atatürk Üniversitesi Diş Hekim Fakültesi Derg. 2016; 26(2). Doi: 10.17567/dfd.20563.

13. Suzen M, Gurler G, Delilbas1 C. Use of blood and blood products in the management of temporomandibular joint
(TMJ) disorders: A systematic review. Yeditepe Dent J. 2019; 15(1): 98-103.

14. Senturk MF, Yazici T, Gulsen U. Techniques and modifications for TMJ arthrocentesis: A literature review. Cranio. 2018; 36(5): 332-40.

15. Tvrdy P, Heinz P, Pink R. Arthrocentesis of the temporomandibular joint: A review. Biomed Pap Med Fac Univ Palacky Olomouc Czech Repub. 2015; 159(1): 31-4.

16. Keskinruzgar A, Cankal DA, Koparal M, Simsek A, Karadag AS. Investigation of the effects of temporomandibular joint arthrocentesis on blood volume of the retinal structures. $\mathrm{J}$ Dent Anesth Pain Med. 2019; 19(1): 37-44.

17. Vaira LA, Soma D, Meloni SM, DellBversana Orabona G, Piombino P, De Riu G. Vertiginous crisis following temporomandibular joint athrocentesis: a case report. Oral Maxillofac Surg. 2017; 21(1): 79-81.

18. Efeoglu C, Koca H, Calis AS. Temporomandibuler eklem artrosentezinin ilginç bir komplikasyonu: Olgu sunumu. Cumhur Dent J. 2010; 13(2): 63-6.

19. Tozoglu S, Al-Belasy FA, Dolwick MF. A review of techniques of lysis and lavage of the TMJ. Br J Oral Maxillofac Surg. 2011; 49(4): 302-9.

20. Aliyev T, Berdeli E, Şahin O. An unusual complication during arthrocentesis: N. facialis paralysis, with N. lingualis and N. alveolaris inferior anesthesia. J Dent Anesth Pain Med. 2019; 19(2): 115-8.

21. Yavuz GY, Keskinruzgar A. Evaluation of complications of arthrocentesis in the management of the temporomandibular joint disorders. Galore International Journal of Health Sciences \& Research. 2018; 3(2): 50-3.

\author{
Correspondence to/Autor za korespondenciju \\ Kivanc Berke Ak \\ Department of oral and maxillofacial surgery, \\ Faculty of dentistry Istanbul Medipol University, \\ Istanbul, Turkey \\ email:kivancberkeak@gmail.com
}

